\title{
Experience in Development and Implementation of an Information Management System in a Technical University
}

\author{
Khurshed T. Maqsudov ${ }^{1}$, Khurshed A. Khudoyberdiev ${ }^{1}$, and Parviz A. Soliev ${ }^{1 *}$ \\ ${ }^{1}$ Khujand Polytechnic institute of Tajik technical university named after academician M.S. Osimi, \\ Khujand, 735700, Tajikistan
}

\begin{abstract}
This article discusses the experience of developing and implementing a university management information system, as part of the implementation tasks in accordance with the Regulation on the credit system of education in higher professional educational institutions in Republic of Tajikistan, which was approved by Ministry of education and science of Republic Tajikistan from 30.12.2016 г., with number № 19/24. This study presents the general results obtained during the automation of document management (workflow of documents) in university based on a management information system of Khujand Polytechnic institute of Tajik technical university (KPITTU). It is described the functionality of the system based on the conceptual document management scheme at the university. It is given the descriptions of the proposed multi-module system architecture with a brief description of each module. The main tasks pursued by the management information system are considered: ensuring effective management and transparency of the organization activity at all levels, information storage, data management and access regulation, formalization of the activities of each employee, optimization of business processes, saving of resources by reducing the cost of managing paper records. Optimization of educational processes and decision making for university management is analysed. Determining the efficiency from embedding automation in KPITTU is given.
\end{abstract}

\section{Introduction}

Effective management of the educational process is one of the most important managerial tasks at the university, which covers a large number of people involved in this process students, teachers, educational support and administrative and management personnel, and directly affects the conditions of their work and study. At the same time, normative documents regulating educational activities provide a great leeway for their implementation in a particular university. Consideration of all available opportunities and their effective implementation require significant labor costs for management personnel. The problem is aggravated by the transition to a new education management system generated by the

* Corresponding author: psoliev@gmail.com 
accession to the Bologna Declaration and the corresponding significant change in regulatory documents.

In general, there is mostly only one serious factor that impedes the more active introduction of information systems in all areas of university management and the organization of university life, it is the unpreparedness of many universities for the daily and systematic use of information systems in their activities.

Obviously, carrying out of measures to informatize management procedures for the educational process, in principle, can significantly improve the quality of management and reduce its complexity. Currently, there are a large number of educational process management systems, representing both initiative and commercial developments. Most often they are aimed at solving problems such as enrolling, transferring and sending students down; monitoring academic performance of students; the formation of working curricula; distribution of academic load between faculties, departments and teachers; formation of staffing chart; making and adjusting schedules for classes and exams.

The distinctive feature of these tasks is that, on the one hand, they are deeply interconnected, and on the other - they affect the interests of large groups of people with different, though not adverse, interests. For this reason, in particular, the organization of the educational process at the university is very conservative, and the introduction of any innovations meets overt or implicit resistance. The reckless use of information and computer technologies often causes an increase in the labor costs of both teachers and students, with no desired effect, which creates sabotage sentiment and actions. This is especially noticeable when trying to introduce third-party developments that implement a partial solution of managerial tasks, on the one hand, changing established traditions, and on the other, requiring connection with existing information systems. This explains the relevance of modernization and implementation of new units of the educational process management information system adapted to the universities of the Republic of Tajikistan.

The proposed study considers the structure of the educational process management information system, which provides for an innovative, integrated and systematic approach to this problem. Studies on the development and implementation of an management information system have been carried out since 2007 in the framework of the "Establishing Bologna-based internal QA system and web portal for its support" project of the TEMPUS program. The system is implemented in KPITTU named after academician M.S. Osimi for over 10 years and has already noticeably improved the quality of educational process management.

The research consists of six sections, describing the purpose and objectives of the management information system, including the organization of the KPITTU information base, the basic requirements for system architecture, development tools and users of the system, a description for the main units, the possibility of using the KPITTU MIS. Among the analytical capabilities of the KPITTU MIS there are the possibilities of analyzing tests through the management information system, developing and analyzing test materials through the management information system, as well as the capabilities of an MIS as a tool for processing questionnaires.

Considering a university as an object of informatization, it is necessary to rely on the fact that from the point of view of management a modern university is a complex active system that has a wide range of activities with its own business processes and a complex hierarchical structure, it is a dynamically developing system, often exposed to innovations from outside, leading to structural transformations, changes in functionality and data flows, it is, finally, an open system focusing on the both internal and external end user and providing relevant and regularly updated information to the outside world. [1]

In universities, there are various approaches to solving the problem of using management information systems: from the development of local information systems for 
each business process [2] to the implementation of ready-to-use industrial products, but despite this, it is undoubted that today the problem of management dataware still exists and is relevant [3-6].

The choice of means of an educational institution informatization, the technology of their implementation, maintenance and development is determined by the university administration based on the university capabilities (infrastructure, personnel, finances, etc.), the information resources accumulated and the functionality of information systems.

Nowadays the market for educational institution automation systems is quite saturated and there are specialized solutions for these institutions presented. Examples of the products presented on educational market of the Russian Federation are the «TANDEM. University», «Galaxy University Management», «1S:University PROF», «Parus University», etc. Let's take a closer look at some of them.

«TANDEM. University» (http://tandemservice.ru/, developed by «TANDEM SERVICE» LLC) is a broadly based solution for the automation of educational organizations: state and commercial universities [7], as well as educational organizations of secondary vocational education.

Along with conventional tasks solved by university management information systems (such as organizational structure management, personal affairs management, automation of the selection committee, etc.), «TANDEM. University» allows you to organize electronic document management, provide the ability to configure specific automated workstations (AWSs), work with branch and representative offices, provide information services for the library, provide an innovative approach to the educational process organization, carry out standardization and regulation of internal processes based on a database of processes and their patterns.

«TANDEM. University» system has a three-tier architecture: a thin client (browsers, application server), servlet container and database server.

The TANDEM company has completed a number of projects for educational organizations of secondary vocational and higher education, including the Far Eastern Federal University, the Northern (Arctic) Federal University, Moscow State Technical University of Radio Engineering, Electronics and Automation, etc.

Another software product on the market is the "Galaxy University Management» system [8] (developed by the "Galaxy» Corporation). This is a comprehensive IT solution for providing information support for the effective management of the educational process and all financial and economic activities of the university.

The "Galaxy University Management» solution, based on the "Galaxy ERP» system [9], allows to plan the educational process of the training institution and its units in accordance with the second and third generation standards, using the semester and modular principles of the educational process scheduling, to schedule educational classes, to integrate with the web portal and other information systems, as well as solve conventional tasks of university MIS. The solution contains web services and OLAP technologies.

More than 30 universities use the «Galaxy University Management» system, including LETI, Omsk State Technical University, Yugra State University, St. Petersburg State University of Service and Economics, St. Petersburg Medical University, etc.

The «1S: University PROF» software product is a solution for the automation of management activities in institutions of higher professional education [10].

During the educational process planning, the formation and accounting of curricula and work syllabi is provided in accordance with the Federal State Educational Standard FSES3, support for a level system (bachelor, master and specialist), creating, storing and processing of educational process schedules, consolidation of the curriculum disciplines for the university departments and divisions, integration with curriculum accounting programs (loading and unloading data in the format of the Federal State Budgetary Institution 
«Informational and Methodological Center of Analysis» of the Shakhty city, Rostov Region). «1S: University PROF" was developed on the technological platform of «1S: Enterprise 8.2».

«1S: University PROF» is used in North-Western State Medical University, Ryazan State University, Saratov State Technical University, Ural Finance and Law Institute and others. The "1S: University PROF» software product is of interest mainly to those universities that already use $1 \mathrm{~S}$ for managing the accounting, material resources, finance.

The program complex of the MMIS Laboratory is designed to automate the management of the educational process in higher and secondary specialized educational institutions. Its implementation provides a comprehensive approach to solving the problems, a modern educational institution deals with.

The main processes automated by the system:

- development, verification and approval of curricula at all education levels;

- automated scheduling meeting the requirements of the Federal State Educational Standard (FSES);

- preparing the curricula for the state accreditation procedure and verification of compliance with FSES;

- accounting and planning of student contingent;

- formation of the academic load and the list of study groups;

- calculation of staff and the distribution of academic load between teachers;

- creating individual teacher plans

- planning the implementation of the educational process within the semester;

- automatic scheduling based on distributed academic load and individual requests of teachers;

- registration of applicants and the workflow of the selection committee;

- accounting and management of personal affairs of students and graduates;

- student movement control;

- computer and paper testing;

- electronic document management of rating reports;

- monitoring and analysis of student performance;

- printing of diplomas, enclosures and academic certificates;

- flexible role-based control for accessing the system;

- formation of orders and reporting;

- publication of information about the educational process on the Internet;

- management of electronic journals of attendance and performance;

- access to the electronic personal account of the student and teacher;

- an electronic portfolio management with review functions.

A separate subsystem is responsible for the automation of each of the processes that form a single process of learning activity. Each subsystem can work both independently and in combination with others, automatically exchanging the data. Working in a single complex excludes re-entering information, data about the student are accumulated from the moment of enrolment to graduation from the educational institution. The quality management system of MMIS Laboratory is certified for compliance with ISO 9001 standards.

The implementation of the software package allows to:

- accelerate processes through the use of electronic document management;

- increase the efficiency of process control;

- automate the time-consuming operations of calculating and generating reports; 
- facilitate the preparation of reports and statistics;

- increase the image of an educational institution;

- increase the process transparency and delimit the responsibility of employees;

- ensure the availability of all necessary information to each employee.

The Council of the Coordination of Professional Education Quality Management of Rosobrnadzor recommended the information system of the MMIS Laboratory for practical use in educational institutions of all levels to create a quality management system. More than 900 universities and colleges use the MMIS Laboratory software.

Softline company proposes the concept of «Digital University» - a hardware-software methodological complex for the implementation of ICT in the education process, based on the service model of the EEOS «University of the Future». The company has implemented projects in Bauman Moscow State Technical University, Graduate School of Innovation Business of Moscow State University - Joint-stock Financial Collaboration «Sistema», Moscow Finance and Economics University (MFEU), I.E. Repin St. Petersburg State Academic Institute of Painting, Sculpture and Architecture, Moscow Financial University, Higher Military Schools of the Ministry of Defense of the Republic of Kazakhstan, the Sberbank Corporate University of Russia located in Odintsovo Moscow Region, Belarusian State Pedagogical University.

The above review of some of the most popular industrial information systems for higher education shows that the described systems provide a wide range of automated business procedures. However, it considered that all industrial university management systems are based on enterprise management ERP-systems, regardless of their industry affiliation. Implementation of a ready-made industrial ERP-system is a laborious and rather time consuming process. Such an implementation is not limited to the installation of ready-touse software. Moreover, this is to a large extent the actions for changing the main activity of the institution (its business processes), aimed at more complete compliance with the logic laid down in the system - reengineering, i.e., the reorganization its own activities in accordance with the business logic laid down inside the finished ERP-system.

It is obviously that highly qualified specialists are required to adapt the ERP-system, who will install, finalize the software modules and/or create new modules and implement it.

The basic functionality of ERP-systems does not modules that automate the features of the university activity related to the educational process, scientific research, etc. The finished systems consider that the university is an «active system», the accounting units of the educational process management subsystem - students and teachers - are active, they are directly involved in the business processes of the university: independently choose or form a curriculum, study according to individual plans, etc.

For many years, a large number of higher educational institutions were engaged in fragmentary automation of the university, i.e., the development of separate management subsystems for various types of activities. And only a few universities, including St.Petersburg State University of Information Technologies, Mechanics and Optics [11], Udmurt State University, Vladivostok State University of Economics and Service [12], etc., began to develop, implement and support their integrated university management systems.

Automation of university management, in particular, management of its educational process, is still one of the topical areas of university informatization. Moreover, the need to solve this problem, the requirements for the information system providing this solution are strengthened because of introduction of strategic planning at the university and the creation of a quality management system.

University management information systems (UMIS [ISU-VUZ]) were developed in the last century and improved with the development of computer technology and computer software and mathematics. Thus, the Khujand Branch of Technological University of 
Tajikistan (KBTUT) was one of the first in 2007 to create a MIS in the Republic of Tajikistan (RT), and on this basis for the first time the subsystem «Teacher UMIS » was created by the university staff. In the same period, the institute began the active introduction of an automated management system in the educational process, including the organization and control of the learning process [13-15].

Over the next five years, the subsystems «Educational process», «HR», «Payroll accounting», etc. were developed and introduced into university management practice. Currently, a full range of university management subsystems based on modern computer technologies are functioning at KPITTU, providing control over the progress of the educational process, planning at all stages of the university, accounting for labor and material resources, etc.

The conceptual model of the university management information system is shown in Figure 1. It covers all aspects of the organization's activities, which formally represents a complex hierarchical system with a large number of structural elements and a significant number of connections between them. MIS includes three main subsystems. These are «Control educational process», «Planning educational process» and «Registration center», as well as additional subsystems: «Accounting», «HR», «Information support of the educational process», "Workstation of the Student» and «Workstation of the Teacher». All subsystems are directly or indirectly interconnected. The management decision-making system is entrusted to the university administration, which receives the necessary information from the information technology center. Recommendations for managerial decisions come from the functional units of the university: student registration center, deaneries, departments, accounting, etc.

All subsystems form a single information field, based on a database management system and a set of decision support models. The formation of the initial student body is carried out by the «Applicant» subsystem. Monitoring the results of its work is carried out directly by the administration and the executive secretary of the university admissions committee. The subsystem generates statistics, such as grades from the school certificate, school achievements, the results of the entrance exam at the national testing center, residence and school number, etc. 


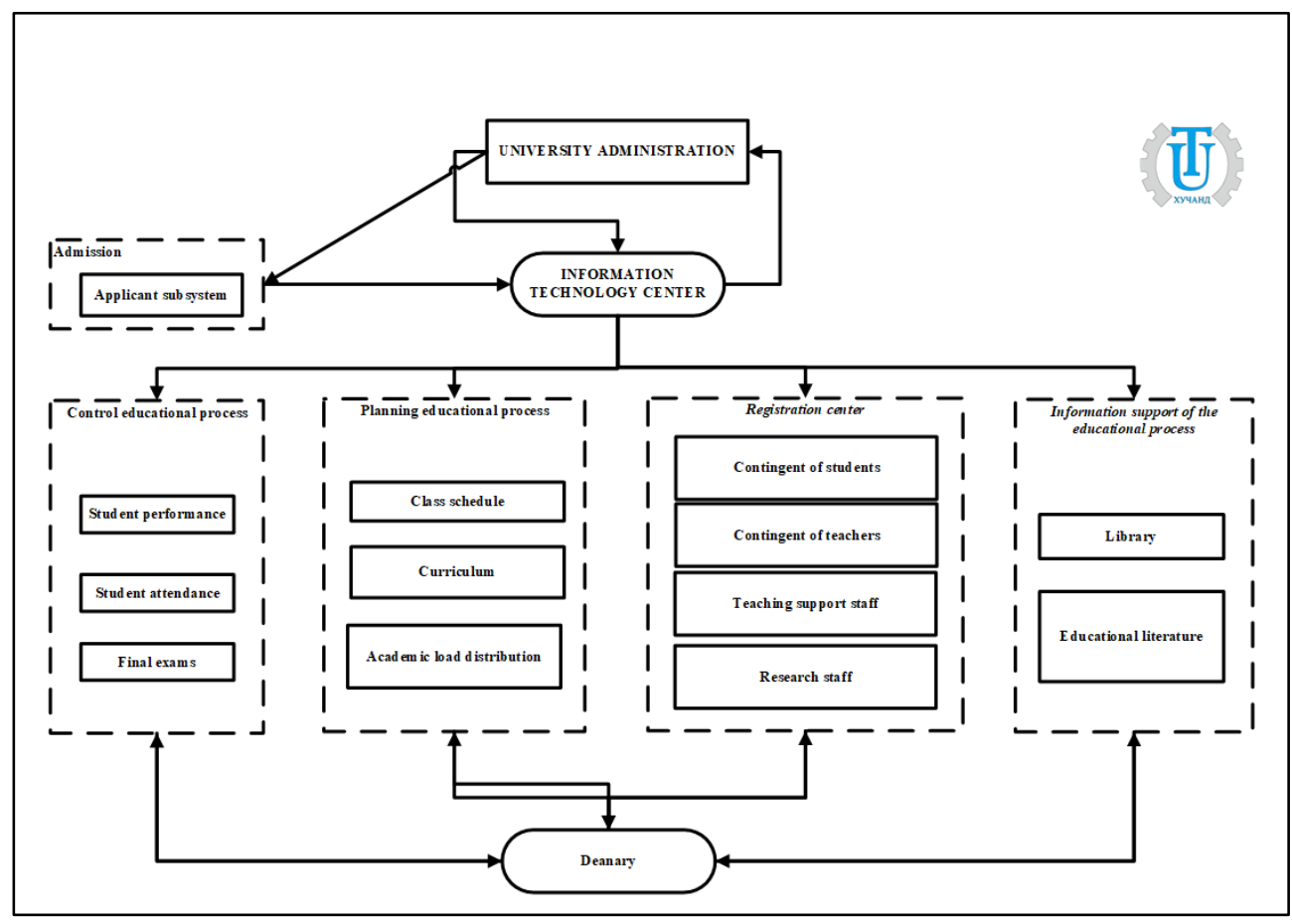

Fig. 1. Conceptual model of KPITTU MIS.

This information is also transmitted to higher authorities to evaluate the performance of school institutions and forecast staffing in the RT. The subsystem provides operational control over the course of the entrance exam, prints examination sheets and other documentation. Enrolled applicants are formed in the base of the «Contingent of students» module of the «Registration centre» subsystem. This shows the consistency and unity of the information, system and mathematical software of all subsystems included in the UMIS. The « Contingent of students » module, in our opinion, is the most important in the entire university management system. It provides the necessary information to all the functional units of the university and primarily deaneries, accounting, the training department.

The mentioned subsystem has three more modules, which are filled with information by the personnel department. Control of the current work of students is performed by the «Control educational process» subsystem. It includes three modules that fully determine the main parameters of the educational process. The «Planning educational process» subsystem is equally important. It includes modules that formulate strategic and operational plans for the educational process. The latter include modules «Class schedule» and «Academical load distribution». The logical structure of the MIS, shown in Figure 1, is typical and operates with some deviations or features in most universities in the country. A focus should be also made on the relationship of educational and scientific work carried out at the university.

The rating of a university is determined by the quality of specialist training and the level of fundamental and applied scientific research, as well as development activity carried out for industrial and commercial organizations in the region. During the learning process, students also take part in scientific work, which is a good professional training for future production «leaders». 
Mathematical methods and models were shown above in a number of cases to be used to support managerial decision-making in higher education institutions. It should be noted that the MIS is constantly updated with these tools.

\section{Objective and tasks of the management information system}

At present, the education quality improvement is one of the urgent problems. The problems of managing higher education institutions are becoming increasingly important in the context of increased competition among educational organizations. Their complexity and relevance determine the versatility of universities, the variety of funding sources, the variety of forms and types of educational, scientific, industrial and economic activities, the need to monitor the market of educational services and the labor market (including the need for employment of graduates), the need to adapt to continuously changing economic conditions.

One of the tools for effective university management is the informatization of scientific and educational activities. Moreover, the degree of university informatization is one of the most significant factors in determining the university competitiveness.

The issues of educational processes informatization and implementation of the information system in the educational process are considered in the writings of scientists: M.I. Nesterov, O.V. Loginovsky, V.V. Kryukov, K.I. Shakhgeldyan, A.S. Zaitsev, V.Yu. Emelyanov, I.V. Voronin, B.T. Torobekov, N.Zh. Saitov, T.A. Pogromskaya, S.N. Tereshchenko, A.A. Mytnik, A.P Klishin, T.V. Moshkova, A.V. Merkulova, V.N. Vasiliev [16-26]. In their work, cientists consider the design and development of university MIS. However, the support and development of own disparate information systems is becoming a factor constraining the development of universities, since often internal IT departments are not able to perform this task. In many universities, automation of management systems has a «patchwork» nature, often limited to installing only accounting programs. In addition, the financial activity IT support requires the greatest possible reliability, a great attention should be given to the issues of protection of information systems.

The main purpose of the university management information system is to improve the management of higher education institutions and the quality of the educational process. This goal can be achieved by automating the solution of applied problems: the educational process planning, creating a university portal and information reference system.

Due to the fact that the MIS is used to solve tasks for various purposes, its structure should include various applications and subsystems for the admission campaign, the educational process, information and methodological resources management, the student body management, monitoring and controlling academic performance and attendance, workflow organization, decision support, scientific activity management, financial planning and accounting, as well as for the administrative activities management and so on. Additional difficulties relate to the need to reorient the university education system in the competence-credit approach and a two-tier system of specialist training. MIS complies with the following basic principles and elements of e-government [27]:

1. Government network service - MIS operates in a single computer network of KPITTU, whose buildings are located in various parts of the city and are connected by an optical fibre network. The network is also accessible through many Wi-Fi routers from anywhere in the buildings using any device.

2. Paperless government - the institute workflow is mainly carried out by the MIS. Student's electronic applications, the formation of orders, electronic confirmation of all actions to organize and manage the educational process, the use of electronic resources from documents to training materials. 
3. The government working on the knowledge basis - in the MIS, many of the operations are performed directly by the system itself based on algorithms, which make decisions based on the analysis of input data.

4. Transparent government - in the MIS, actions and decisions are available to a wide range of users. Parents of students also have access to the training process of their children.

Using a single computer network, the MIS in the information space of KPITTU interacts with the software of centres of testing and distance education, as well as with the website of the institute.

An educational portal of distance education on the global Internet has been functioning at KPITTU since 2013. The remote portal and the MIS work together in synchronization mode, i.e. there is a timely exchange of necessary information and documents. The portal is also developed by employees of the institute itself. It allows to give video lectures, webinars, forums, chats, to check work of students, to conduct online tests and exams [28].

A mechanism is being developed at the institute so that the reporting results of the MIS are transmitted to the institute's website through automated specialized modules. The modules will provide information transmitting from the MIS to the website as an RSS-feed, automatically and timely updating the data on the website from the MIS databases.

The system allows each participant in the educational and other work processes (student, teacher, ..., director) to operate with only that data and perform only those operations that fall within the competence of this participant. Each user has a username and password, which determine his access level and status to MIS data and operations.

Through its interface authorized persons appointed by the director provide the login for new users and the suspense the login functioning for existing users.

A communication was organized between the participants of the educational process from bottom to top and top to bottom along the vertical of access to MIS data. Within the framework of a single system, the implementation of the management process is the collection of data on participants and workflow objects directly through the participants themselves, analysis of input data, optimization and error detection, their correction before use, timely making management decisions, monitoring the implementation of decisions [29-31].

Entering basic data on students in MIS is performed only through online order projects of the selection committee with online approval by the head. Changing the data of students, as well as returned from suspension and transferred students, is performed also through online order projects from the registrar's office with online approval by the head. The data of teachers and staff can be changed through online order project from the personnel department with online approval by the head. Other data can be changed through the online approval of the electronic version in the system by the responsible persons. Entering data on work processes is performed directly from the interface of the data producers (student, teacher, etc.) under the control of immediate superiors (dean, department head, etc.) with approval by the head.

The following tasks are primarily solved in the framework of MIS [32]:

1. Management of the educational process (nomenclature of affairs and organizational and administrative documentation; selection committee, faculty, department, magistracy, doctoral studies, scheduling; accounting performance and attendance, etc.).

2. Organization of educational activities (providing access to teaching materials and a digital library, automated knowledge test, the use of electronic simulators, etc.).

3. Management of scientific activities.

4. Financial and economic activities; statistics and reporting, etc.

Many real processes in the MIS have a global, «open-end» nature and require connection to systems of various purposes for their implementation. Therefore, the identification and description of end-to-end business processes for their subsequent 
implementation in the system is one of the most important tasks of the MIS design. In turn, the MIS should provide support and implementation of end-to-end business processes in a single information environment and in real time.

MIS is developed in open source systems and is continuously improved, being today one of the few high-readiness software systems that implements a systematic approach to managing the educational process based on information technology. The system continuously requires the development and implementation of additional modules that improve the management process. MIS implemented in KPITTU performs the following tasks (see Figure 2).



Fig. 2. Tasks of management information system.

The mentioned tasks allow to ensure the organization and control of the educational process, electronic document management, data provision and analysis, management decision-making and control of its implementation, determining the student's workload and monitoring its implementation, determining the teacher's workload in educational, methodical, scientific, tutorial work and monitoring its implementation , input, accounting, control and analysis of student's academic achievements - rating assessment system, creating and managing the implementation of class schedules, activity (based on workstations) of the main participants in the educational processes of the university: rector, dean, department head, inspector of the registrar's office, teacher, student.

The software implementation of the task of educational process management of the university can be built only on the basis of a systematic approach, when individual subsystems are linked in a single database, with which the departments of the educational institution (educational department, deans, departments, human resources, accounting) work using information and network technologies.

The software package automates the following tasks: curricula (work of the training department); control of student performance and attendance (work of deanery); educational loads of departments and teachers (departments' work); schedule development (automatic algorithm); automation of accounting and reporting (accounting department), teaching staff (work of the personnel department); automation of the registration office, a base of graduates creation.

Figure 2 shows that the MIS performs the following tasks: centralization, storage, systematization and processing of all data in a single university database; providing the ability to collect and analyse information in real time; ensuring the timely implementation of procedures and rules for the educational process management; operational support of the education quality monitoring system; organization of interactive communication between students, teachers and all services of the institute; organization of automatic reporting of the 
educational process results; providing students and teachers with simultaneous online access to the educational process results and electronic library resources.

Ability to synchronize information from non-network programs of the university with the MIS. For example, the institute has an autonomous program for exam materials preparation, installed in the teacher's laptop - the task is downloaded from the MIS using the teacher's interface to create the exam material for a specific discipline in XML format, the material is created without contacting the MIS, then it returns to the MIS using the same interface. The subsystem of inquiries from the MIS for the program of RT universities statistics of the Ministry of Education and Science. Using the interface of the training department head, the necessary data is generated in the MIS in XML format, the necessary corrections are entered and sent to the DB, then they are transferred for the statistical program.

The introduction of MIS motivates teachers to study and use office and service programs, to develop the ability to work on a local network and the Internet, work with projectors, electronic boards, network equipment.

\section{The main requirements to the architecture of the system}

University management in modern conditions is impossible without the comprehensive automation of its activities. In educational practice, each university is considered as a complex organizational system consisting of an interconnected set of subsystems (activities) - managerial, academic, scientific, economic, business, marketing. Each of these systems should be considered as an individual control object. Lack of timely, relevant and reliable information leads to ineffective decisions at different levels of university management.

At present, the use of modern information and communication technologies, data processing tools, and other attributes of informatization can contribute to the optimization of dataware for university activity management. Informatization of university management allows to get a powerful information and analytical apparatus, allowing to quickly receive a variety of statistical and analytical reports on any direction of the university activity and make effective management decisions based on them. All complex aggregate of university management based on information technologies form a so-called management information system (MIS) modified into various advanced systems such as automated management information system (AMIS), integrated automated information system (IAIS), etc.

Figure 3 shows the architecture of the KPITTU management information system.

One of the tasks of UMIS is to increase management efficiency. As part of this task a management information system was developed and implemented at the Khujand Polytechnic institute of Tajik technical university named after academician M.S. Osimi (KPITTU). The system has been successfully operating for over 10 years. This development is unique because it was created by a team of professional developers, teachers with many years of experience and students in the framework of final qualification works. 


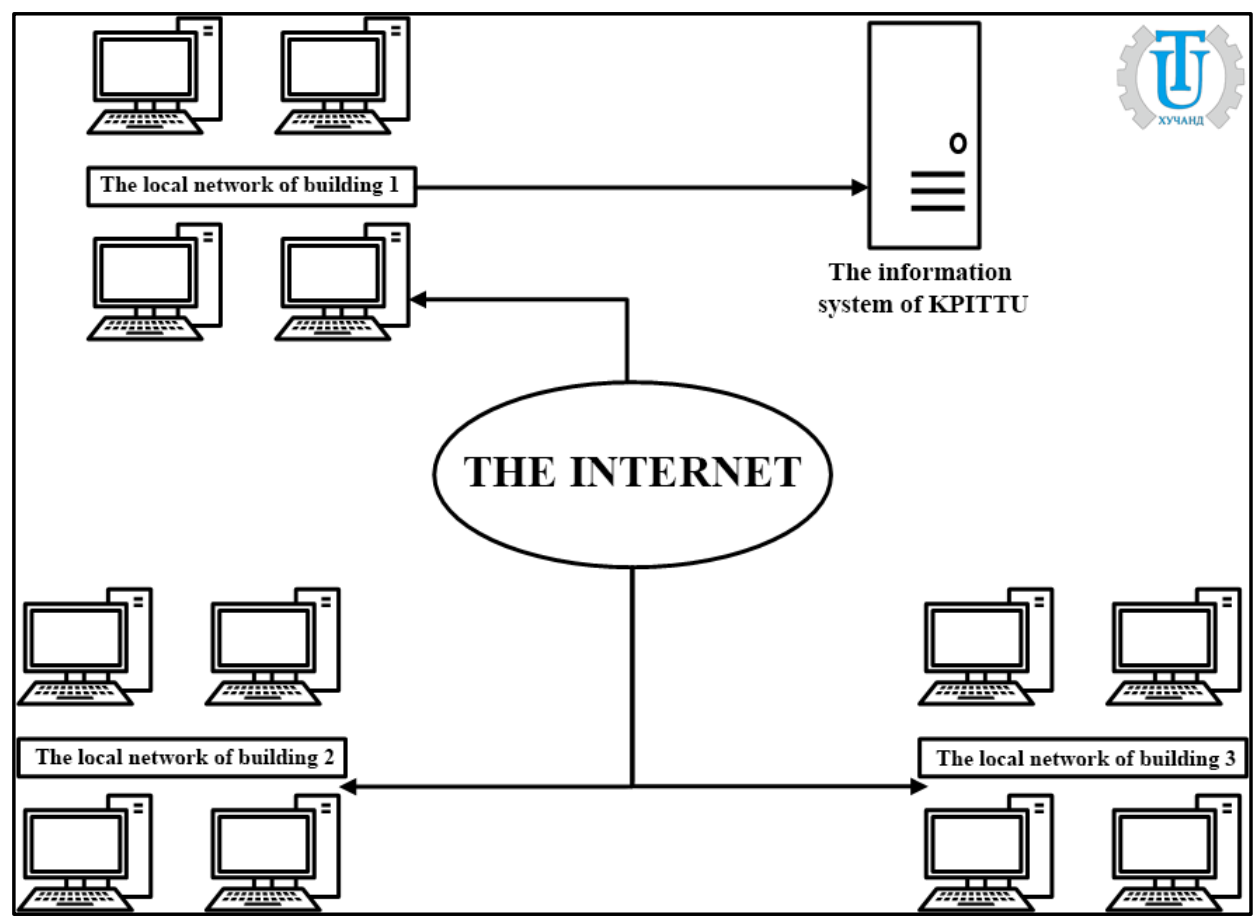

Fig. 3. Management information system architecture.

The system provides a comprehensive thorough support for educational process management. It implements the following principles: cross-functional interaction between departments, strategic planning, monitoring the effectiveness of the university activity, resource support of implemented programs, greatly facilitates the effective teamwork management in the development and implementation of management decisions (see Figure 4).

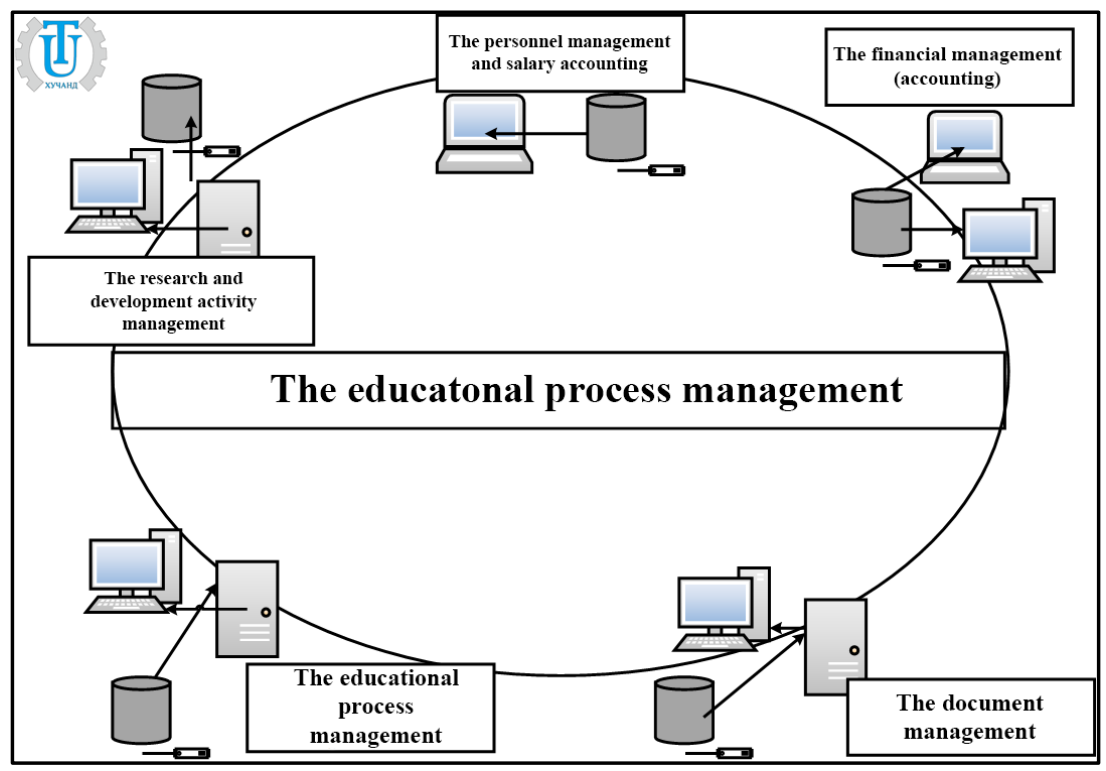

Fig. 4. Structure of interaction between KPITTU MIS departments. 
During the development, first of all, the wishes of users were considered and necessary adjustments were made, which allowed to consider the numerous features typical for real processes of managing educational institutions of the Republic of Tajikistan.

The introduction of KPITTU MIS allowed to get certain results:

- to achieve transparency of all educational institution management processes, to improve the planning and control of the educational process;

- to promptly provide the organizers of the educational process of senior and middle management with reliable data, increase the efficiency, accuracy and correctness of management decisions;

- to increase the control of the quality of the educational service provision to the student;

- to get an economic effect due to optimization when planning the academical load of the professional and teaching staff;

- to increase the level of professional competence of graduates by using electronic training systems in the educational process.

Currently, the KPITTU MIS is a convenient and indispensable tool for each participant in the educational process, which significantly reduced the routine work of department employees, freed up time for paying attention to the student and the quality of educational services. The object model underlying the KPITTU MIS was developed considering the best experience of domestic and foreign educational projects known to us (see Figure 5).

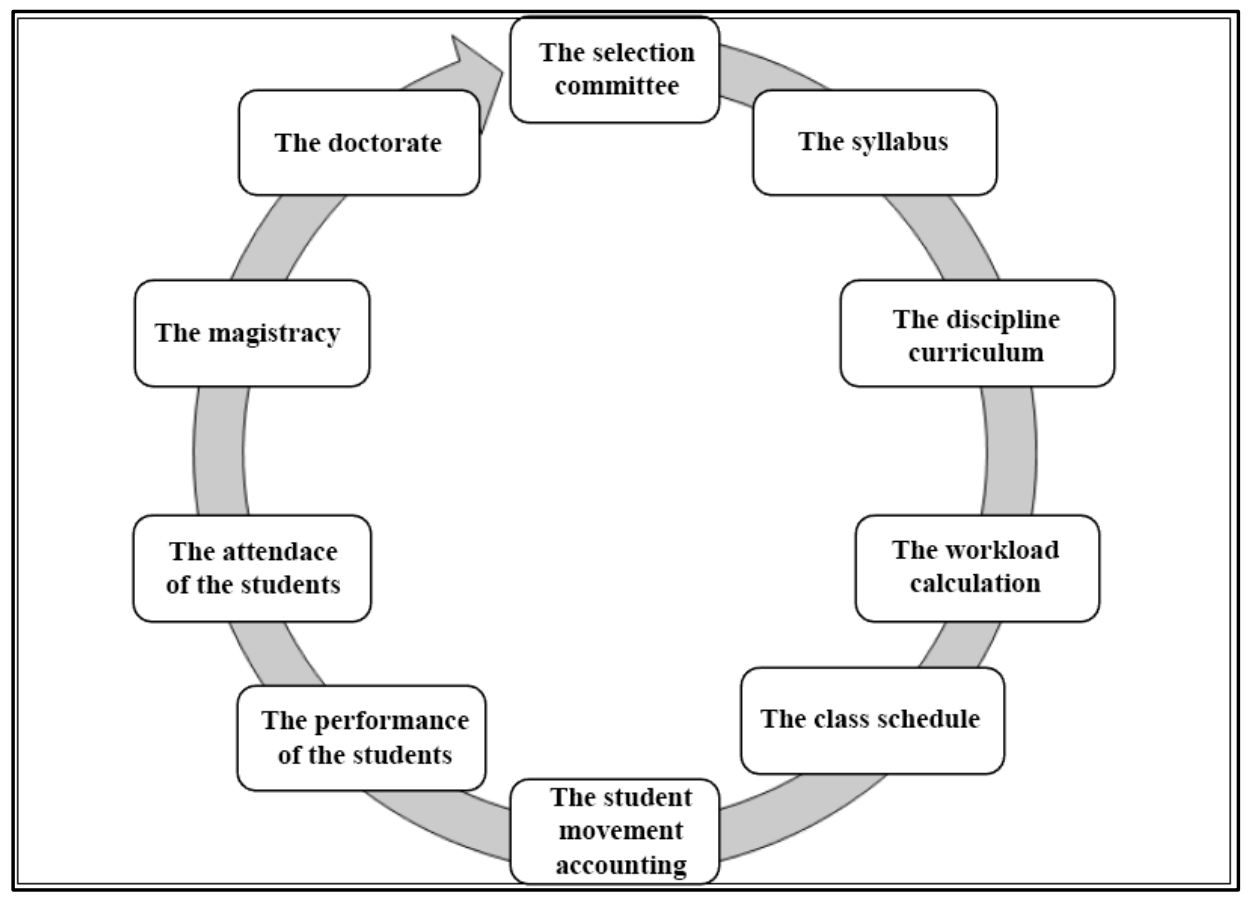

Fig. 5. The object model of KPITTU MIS.

Moreover, an electronic document management system has been created on the basis of the process approach, which allows to timely report and analyse the issues raised in any KPITTU department (see Figure 6).

The order introduction systems have been developed and implemented, which ensure the placement of orders and instructions and their distribution to all interested parties. The 
integration of orders on the student body and student management system has been introduced. Systems for monitoring the director's instructions execution have been developed. The process of managing administrative documents at the department level (director-manager, department-executor) with the forwarding of orders and reporting of executors is regulated. Subsystems for managing scientific projects and process automation for transferring educational and methodological developments to the publishing house have been introduced. The teacher load calculation is introduced. Automatic absentee management of employees is implemented.



Fig. 6. Process approach to the document management of KPITTU MIS.

\section{Conclusion}

The KPITTU MIS software package is constantly being developed to improve quality and add new functions in accordance with changes in the educational policy in Tajikistan, and it provides in real time:

1. Assistance in improving the training quality and the effective work of all participants in the educational process.

2. The ability for students to access educational materials, data on their studies, determining the elective disciplines (individual learning path), writing applications, knowledge testing,

3. Access for managers and responsible persons to accurate and high-quality data within their competencies.

4. The educational process optimization and high-quality, timely decision-making by management entities at the university.

\section{References}

1. S.H. Kostjukevich, A.G. Marahtanov, O.Y. Nasadkina, Y.E. Shtivelman PetrSU, Information Analytical Integrated System (IAIS): approaches, solutions, development trends, University Management: Practice and Analysis, 5, pp. 95-105 (2015) 
2. Mihaela Drgana, Diana Ivanaa, Raluca Arbaa, Business Process Modeling in Higher Education Institutions, Developing a Framework for Total Quality Management at Institutional Level, Procedia Economics and Finance, 16, pp. 95-103 (2014)

3. Rasha Ismail, Fadi Safieddine, Ashraf Jaradat, E-university delivery model: handling the evaluation process, Business Process Management Journal, Vol. 25, No. 7, pp. 1633-1646 (2019)

4. E.N. Babin, Digitalization of the university: construction of the integrated informational environment, University Management: Practice and Analysis, 22(6), pp. 44-54 (2018). https://doi.org/10.15826/umpa.2018.06.057

5. O.L. Kurilova, Primeneniye geneticheskogo algoritma dlya optimizatsii uchebnogo plana [Using a genetic algorithm to optimize the curriculum], Informatsionnoupravlyayushchiye sistemy [Management Information Systems], No. 3, pp. 84-92 (2013).

6. Zhibing Liu, Huixia Wang, Hui Zan, Design and Implementation of Student Information Management System, 2010 International Symposium on Intelligence Information Processing and Trusted Computing

7. Unified educational process management information system Tandem University [Electronic resource], Ekaterinburg, (2014). http://elar.urfu.ru/bitstream/ 10995/24628/1/notv-2014-104.pdf

8. Automated system of university management Galaktika [Electronic resource], Moscow (2014). http://www.galaktika.ru/vuz

9. D.A. Bushkovsky, "Galaktika»; sovremennye IT reshenija dlja vuzov ["Galaktika"; Modern IT solutions for universities], Informacionnaja sreda vuza XXI veka [University Infomedia XXI Century], Materialy $\mathrm{V}$ Mezhdunarodnoj nauchno prakticheskoj konferencii [Proceedings of the $\mathrm{V}$ International scientific and practical conference], Petrozavodsk, pp.46-49 (2011)

10. Kartochka reshenija IS Universitet PROF [Card solutions 1C PROF University]. http://solutions.1c. ru/catalog/university prof (accessed 09.10.2015).

11. Upravlenie $v$ vysshej shkole: opyt, tendencii, perspektivy [Management in Higher Education: Experiences, Trends, Prospects], Analiticheskij doklad [Analytical Report. Moscow, Logos, pp.328-356 (2005)

12. V.V. Kryukov, K.I. Shahgeldyan, Korporativnaja informacionnaja sreda vuza: metodologija, modeli, reshenija [Corporate information environment of the university: methodology, models, solutions], Monografija [Monograph], Vladivostok: Dal'nauka, p. 308 (2007)

13. A.T. Maksudov, Kh.T. Maqsudov, P.A. Soliev, E.R. Nuretdinova, Avtomatizirovannoye rabocheye mesto «Dekan» informatsionnoy sistemy upravleniya vysshim uchebnym zavedeniyem (ISU VUZ) [Automated workstation «Dean» of the management information system of a higher educational institution (UMIS)], Intellectual Property Registration Certificate №095TJ (2009)

14. A.T. Maksudov, Kh.T. Maqsudov, P.A. Soliev, E.R. Nuretdinova, Avtomatizirovannoye rabocheye mesto «Prepodavatel'» informatsionnoy sistemy upravleniya vysshim uchebnym zavedeniyem (ISU VUZ) [Automated workplace «Teacher» of the management information system of a higher educational institution (UMIS).], Intellectual Property Registration Certificate №0118TJ (2009)

15. A.T. Maksudov, Kh.T. Maqsudov, E.R. Nuretdinova, «Dvizheniye kontingenta stedentov» informatsionnoy sistemy upravleniya vysshim uchebnym zavedeniyem (ISU $V U Z$ ) [The subsystem «Movement of the contingent of students» of the management 
information system of a higher educational institution (UMIS)], Intellectual Property Registration Certificate №0111TJ (2009)

16. M.I. Nesterov, Model' informatsionno-analiticheskoy sistemy vysshego uchebnogo zavedeniya, osnovannaya na arkhitekturnom podkhode [Model of information and analytical system of a higher educational institution based on an architectural approach], Vestnik Yuzhno-Ural'skogo gosudarstvennogo universiteta. Komp'yuternyye tekhnologii, upravleniye, radioelektronika [Bulletin of the South Ural State University. Computer technology, management, electronics], Release 13, No. 4, pp.120-128 (2013)

17. O.V. Loginovskiy, Primeneniye metodov arkhitekturnogo podkhoda $v$ razvitii informatsionnoy sistemy krupnogo vuza [Application of the architectural approach to the development of the information system of a large university], O.V. Loginovskiy, M.I. Nesterov, A.L. Shestakov, Vestnik Yuzhno-Ural'skogo gosudarstvennogo universiteta. Komp'yuternyye tekhnologii, upravleniye, radioelektronika [Bulletin of the South Ural State University. Computer technology, management, electronics], Release 13, No. 4, pp. 150-153 (2013)

18. V.V. Kryukov, K.I. Shakhgel'dyan, Korporativnaya informatsionnaya sreda vuza: metodologiya, modeli, resheniya [Kryukov V.V., Shakhgeldyan K.I. University corporate information environment: methodology, models, solutions], Monograph. Vladivostok: Dalnauka, pp. 301 (2007)

19. A.S. Zaytsev, V.U. Yemel'yanov, I.V. Voronin, Avtomatizatsiya kak osnova optimal'nogo planirovaniya uchebnogo protsessa universiteta [Zaitsev A.S., Emelyanov V.Yu., Voronin I.V. Automation as the basis for optimal planning of the university educational process], Mekhatronika, avtomatizatsiya, upravleniye [Mechatronics, automation, control], № 5, pp. 45-48 (2007)

20. B.T. Torobekov, N.Zh. Saitov, Informatsionnaya sistema v upravlenii vuzom [Information system in university management], Problemy avtomatiki $i$ upravleniya. [Automation and management problems], cientific and technical journal, National Academy of Sciences of the Kyrgyz Republic. Ilim. Bishkek, pp. 198-202 (2008)

21. T.A. Pogromskaya, Informatsionnaya sistema dlya upravleniya priyemnoy kampaniyey $v$ vuze [University Admission Campaign Management Information System], the dissertation of a candidate of technical sciences: 05.13.01, Omsk, p. 175: illustrated (2006)

22. S.N. Tereshchenko, Informatsionnaya sistema upravleniya protsessami planirovaniya, podgotovki, vypuska $i$ raspredeleniya uchebno-metodicheskikh materialov $v$ vuze [Information system for managing the processes of planning, preparation, production and distribution of teaching materials in university], the dissertation of a candidate of technical sciences: 05.13.10, Novosibirsk, p. 198: illustrated (2007)

23. A.A. Mytnik, A.P. Klishin, Opyt vnedreniya informatsionnoy sistemy E-Decanat 2.0 dlya avtomatizatsii upravleniya uchebnym protsessom $v$ TGPU [Experience in implementing the E-Decanat 2.0 information system for automating the management of the educational process at TSPU], Vestnik TGPU [Bulletin of TSPU], No. 1 (129), pp. 189-192 (2013)

24. T. V. Moshkova, Razrabotka sistemy operativnogo upravleniya uchebnym protsessom kafedry tekhnicheskogo vuza [Development of an operational management system for the educational process of the department of a technical university]: the dissertation of a candidate of technical sciences: 05.13.01, Nizhny Novgorod, p. 168: illustrated (2008) 
25. A.V. Merkulova, Issledovaniye i razrabotka korporativnoy informatsionnoy sistemy dlya upravleniya vuzom na osnove tekhnologii otkrytykh sistem [Research and development of a corporate information system for managing a university based on open systems technology]. Abstract of the dissertation of a candidate of technical sciences: 05.13.10, Merkulova Alena Vyacheslavovna, [Place of defense: Moscow Institute of Steel and Alloys], Moscow, Russian State Library Dissertation Department, p. 21 (2007)

26. V.N. Vasil'yev, Modeli upravleniya vuzom na osnove informatsionnykh tekhnologiy [University management models based on information technology], the dissertation of a doctorate of technical sciences in the form of scientific report: 05.13.01, Petrozavodsk, p. 108: illustrated (2001). Russian State Library Dissertation Department, 71 02-5/369-X

27. A.T. Maksudov, Vnedreniye elementov Elektronnogo pravitel'stva v politekhnicheskom institute [The introduction of e-government elements in the Polytechnic Institute], Pervaya mezhdunarodnaya konferentsiya «Prikladnyye informatsionnyye sistemy: problemy modelirovaniya, primeneniya $\mathrm{v}$ razvivayushchikhsya stranakh» [The first international conference «Applied Information Systems: Problems of Modeling, Applications in Developing Countries»], Khujand (2012).

28. A.A. Khudoyberdiyev, Modul' programmnogo obespecheniya onlayn-ekzamenov $v$ VUZe [Software module for online exams at the university], Vtoraya mezhdunarodnaya konferentsiya «Prikladnyye informatsionnyye sistemy: problemy modelirovaniya, primeneniya $\mathrm{V}$ razvivayushchikhsya stranakh» [The second international conference «Applied Information Systems: Problems of Modeling, Applications in Developing Countries»], Khujand (2017)

29. D.R. Saidi, P.A. Soliev, Mekhanizm ucheta i kontrolya rabochego vremeni sotrudnikov VUZa s primeneniyem informatsionnykh tekhnologiy [The mechanism of accounting and control of working time of university employees with the use of information technology], Vtoraya mezhdunarodnaya konferentsiya «Prikladnyye informatsionnyye sistemy: problemy modelirovaniya, primeneniya $\mathrm{V}$ razvivayushchikhsya stranakh» [The second international conference "Applied Information Systems: Problems of Modeling, Applications in Developing Countries»], Khujand (2017)

30. D.R. Saidi, Kh.T. Maqsudov, P.A. Soliev, Podsistema opredeleniya i kontrol' vypolneniya nagruzki prepodavatelya $v$ ISU KPITTU [The subsystem for determining and monitoring the teacher's workload in the KPITTU MIS], Vtoraya mezhdunarodnaya konferentsiya «Prikladnyye informatsionnyye sistemy: problemy modelirovaniya, primeneniya $\mathrm{V}$ razvivayushchikhsya stranakh» [The second international conference «Applied Information Systems: Problems of Modeling, Applications in Developing Countries»], Khujand (2017)

31. Kh.T. Maqsudov, P.A. Soliev, Informatsionnaya sistema upravleniya VUZa kak osnovnoy faktor kachestvo obrazovaniya [University management information system as the main factor in the quality of education], Vestnik PITTU imeni akademika M.S. Osimi [Bulletin of KPITTU named after academician M.S. Osimi], №2 (3), pp.7-14 (2007)

32. P.A. Soliev, Web-servis ISU VUZ «Upravleniya dokumentooborota» [Web-service of the UMIS «Document Management»], Intellectual Property Registration Certificate № 4201900449, (2019) 